\title{
Alarm to Global Hunger Phenomenon and Food Squandering
}

\author{
Bijan Bidabad ${ }^{1}$
}

\begin{abstract}
A quarter to one-third of food materials are wasted every year and about one-sixth of the people of the world, which is about one billion people, are facing malnutrition and about one-third of them are hungry. A hunger tsunami is forecasted for 9 billion people of the world in 2050. Therefore, in order to gain victory on this crisis in 2050 , the rules and the socio-economic framework should be changed to prevent the imbalanced distribution of agricultural products.
\end{abstract}

Keywords: Food, Squandering, Hunger

\section{Introduction}

Damages and wastes are carried out by people into a variety of ways, and usually, no production, transaction, and consumption process can be found which has no damages. The damages of production and consumption processes can be classified in different ways according to the purpose of the study with different applications ${ }^{2}$. Each of these classifications is subject to detailed discussions and regarding the importance of food and its high level of damages and wastes, and the malnutrition and hunger of people, all are subject to review.

Generally, damages occur in the process of production because of poor technology, management, warehousing and sale, lack of proper processing and preserving technology and proper transportation, delivery, packing and supplying to consumers and improper methods of food consumption by consumers as a fraction of household wastes, are the main sources of damages and wastes of food around the world ${ }^{3}$.

The subject is very important from a humanities point of view because a quarter to one-third of food materials are wasted every year and about one-sixth of the people of the world which is about one billion people, are facing malnutrition and about one-third of them are hungry. Due to poor nutrition during embryonic and childhood is the cause of death of one-third of the children of the world ${ }^{4}$. According to Food and Agriculture Organization (FAO), a

${ }^{1}$ (B.A., M.Sc., Ph.D., Post-Doc.) Research Professor of Economics, Monetary and Banking Research Academy, bijan@bidabad.com http://www.bidabad.com.

2 - For example, damages can be classified according to the following groups: Solid Wastes, Liquid Wastes, Gaseous Wastes, Animal by-products ,Biodegradable waste, Biomedical waste, Bulky waste, Business waste, Chemical waste, Clinical waste, Coffee wastewater, Commercial waste, Construction and demolition waste (C\&D waste), Controlled waste, Consumable waste, Composite waste, Demolition waste, Domestic waste, Electronic waste (E-waste), Farm waste, Food waste, Green waste, Grey water, Hazardous waste, Household waste (including Household hazardous waste), Human waste, sewage sludge, Industrial waste (including: slag, fly ash and sludge), Inert waste, Kitchen waste, Litter organic waste, Liquid waste, Medical waste, Mixed waste, Municipal solid waste, Packaging waste, Post-consumer waste, Radioactive waste (nuclear Low level and High level waste, Spent nuclear fuel and Mixed radioactive/hazardous waste), Recyclable waste, Residual waste, Retail hazardous waste, Sewage, Sharps waste, Slaughterhouse waste, Special waste, Toxic waste, Uncontrolled waste, Waste heat, Wastewater, Winery wastewater... http://en.wikipedia.org/wiki/List_of_waste_types

3 - Food wastes include any kind of raw or cooked nourishment which is thrown away. The United States Environmental Protection Agency defines food damages and wastes as "uneaten food". Also refer to:

"The Definition of Waste, Summary of European Court of Justice Judgments". Defra. Updated 2009.

http://www.defra.gov.uk/environment/waste/topics/pdf/ECJCaseLaw20090209.pdf. Retrieved 2009-08-20.

4 - Announcement of Information Centre of United Nations, International Union against Hunger about Food. In this announcement the waste of food has been defined as a "criminal phenomenon" and has asked everybody to decrease waste to zero and do not buy or cook more than need and preserve food through proper methods so that food not to thrown away and before throwing away food, they should think if possible to prepare a tasty soup from the remained food? The announcement has also asked people to persuade governments to implement effective actions for alleviation of hunger and malnutrition. http://www.fao.org/UNFAO/Bodies/cfs/cfs34/index_en.htm 
number of hungry people in the world had reached 105 million in 2009, and about 1.02 billion had malnutrition and hunger which has been the main cause of annual death of 30.5 million children of the world. Families in developing countries on average spend $70 \%$ of their income for food, and this figure is about $15 \%$ to $18 \%$ in industrial countries. A study of hungry people of the world shows $70 \%$ of them are women and girls; while rural women produce $50 \%$ of the world's food.

The number of children suffering from low weight has increased between 2000 and 2005, according to UN reports. Micro-nutrition shortage is one of the most important factors for the excessive low weight of children. It is one of the main health problems in the world. That is to say, vitamin A shortage and therefore we see anemia symptom because of low usage of iron and zinc. These are causes which increased the early death of children and mothers, further decrease the IQ of the children and decrease in quality of life and productivity as well as economic growth in developing countries. According to a report, about 70\% of non-pregnant mothers in India and 50\% of women in subSaharan Africa are suffering from anemia because of the inadequacy of iron consumption. Further, the inadequacy of vitamin A has affected the immunity system of $40 \%$ of children below the age of 5 in developing countries and has increased the average number of death among the children in developing countries. In some countries the figures are more desperate, one of which is related to India with $40 \%$ because of the lack of consummation of the adequacy of vitamin A before school age children.

The UN World Food Program Agency projected to the new record number of world hungry people on the occasion of Global Food Day, and emphasis that helps contribution has decreased to its lowest level of recent years, while the number of hungry people of the world has increased because of the combined effects of the increase in the food price, financial crisis, and climate change. In this regard, the executive director of the World Bank ${ }^{5}$ says: The main concern of world policymakers today is concentrated on the miseries caused by the global crisis. But, the real crisis is hunger and malnutrition... 75\% of the people of the world live in villages, and most of their lives are tied to agriculture which is the basic tool to fight hunger, malnutrition, and alleviation of poverty and sustainable development ${ }^{6}$.

In the complaint to disregarding the vast hunger of the world, in a symbolic movement in May 2009, Jack Dief, director of Food and Agricultural Organization of UN, went on 24 hours strike in FAO headquarter in Rome. He went on a hunger strike to recall international organizations to fight against spreading world hunger. By expressing his worry about the increasing number of hungry people of the world, he asked all people of the world to join this strike. Dief mentioned that we have every kind of natural resources and techniques to abolish world hungriness, and only political reasons prevent us from doing so.

All most 30\% of foodstuffs in America, which amounted to 48.2 billion dollars in 2008 are wasted. A large portion of this figure is food wasted from restaurants, hotels, coffee shops and schools, university cafeterias, and office restaurants ${ }^{7}$. All these food wastes are because of the squandering of foodstuff more than needed and are thrown away. Generally, purchasing and keeping more food than needed, increases other costs such as transportation and preserving, which are usually forgotten. In this regard, it should be mentioned that according to the published data, about $18.7 \%$ of the world energy is used to preserve foodstuff in refrigerators ${ }^{8}$.

The FAO has predicted about a hunger tsunami in Food Production Outlook for 9 billion people of the world in 2050. It has been mentioned in their report that in order to gain victory on this crisis in 2050, the rules and the socioeconomic framework should be changed to prevent the imbalanced distribution of agricultural products. However, within the first half of the 21 century, amount of food needs to be doubled, where world temperature will increase,

Also see:

http://www.iaahp.net

Olivier De Schutter, 2009, UN Special Rapporteur on the right to food, Accountability to combat hunger. http://www.iaahp.net/fileadmin/templates/iaah/WFD2009/contributions/IAAHeditorial_DeSchutter_EN.pdf

5 - Ngozi Okonjo-Iweala.

6 - All-Africa Global Media, Feb., 19, 2008.

7 - Robin Shreeves, The Shocking Statistics of Food Waste (and How to Keep Your Contribution to the Problem at a Minimum) Published on August 25th, 2008, Home \& Garden

${ }^{8}$-http://www.refrigeratorsaver.com/ 
agricultural production capacity will decrease, while demand for these products will also increase. Hence, if we do not think essentially to solve this problem, the hunger crisis will be indispensable. A recent FAO study shows that in order to feed 9 billion people in 2050, we need to increase agricultural production by 705 , and most of this increase should be in vital strategic productions such as grains. One of the instances that FAO proposes is an equal distribution of food and resources. According to the FAO report, grain production, which is about 2.1 billion tons per year at the present time, should be increased by one billion ton. Meat production should increase from 200 million tons to 470 million tons in 2050 . Out of these products, about $72 \%$ of this amount will be spent in developed countries, while, at the present time, the figure is $58 \%$ of total meat production. The report makes this clear that in order to eliminate hunger in 2050, it is necessary to increase investment in agriculture by $60 \%$ until 2050. It may be pointed out here that the Human Right Declaration in 1948 considers not being hungry and removal of malnutrition as an integral part of human rights which has been again confirmed by Children Right Convention in 1989, but UN and the global community have not done any decisive action about this difficulty yet.

On the other hand, religiously speaking, the holy Quran has considered over-consumption and squandering (spending more than need) as a forbidden act. Al- Quran commands: "It is him who has created gardens with or without scaffold and date roots and fields with various fruits and olive and similar and un-similar pomegranates. When they become fruitful, eat their fruit and give God's share when you pick them and do not squander, because God does not like squanderers"'. The share of God here certainly means paying "Zakut" (an Islamic tax) to poor and helpless people. In Surah of Esra, God commands: "Pay the rights of helpless people, and those tired up in roads and do not squander at all. Squanderers are brothers of Satan, and Satan was not grateful to his God."

It is quite clear that human beings are families, and in the above verses of the Quran, when it refers to human beings, it means to all the people around the world. This verse considered specific rights in the properties of people for family and helpless people, and there is no difference between Asian, African, American, or European helpless people. Wherever the helpless is located, they are needy, and we have to pay his right, which is contained in the properties of wealthy peoples.

Quran again commands: "Eat and drink and do not exceed limits because he does not like squanderers"11. This subject, according to the commands of God, there is urgently needed for a global system to find a basic solution to the problem and put it at the top of the international policymaking agenda. Ethically, it is not appropriate for human being dignity to see some people throw away $30 \%$ of their foodstuff while some others suffer and die because of hunger and malnutrition.

The UN World Food Program Agency referred to a new record of the number of hungry people of the world on the occasion of International Food Day and made it clear that the agency had agreed to help by providing food for 108 million people in 74 countries this year. But some countries reduced the quota and pended the quota of some others because of the budget deficit. At last, it has managed to secure only 2.9 billion dollars of 6.7 billion dollars budget from donor countries in 2009. By a simple commensuration, one can find out that just America's food squanders, which was about 48.2 billion dollars in last year, 775 million hungry people could have been fed. And if we add the amount of squandering by Europe, Japan, and wealthy oil-producing countries to this figure, we can see that their squandering amounts reached several times as much of the food needed for hungry and malnutrition people of the world.

Unfortunately, food is considered as other goods, and no difference is considered between essential needs and luxury goods. Wealthy people can buy everything, while poor people usually can not afford to buy their basic needs. Human being has biologic needs of food, which is quite different from their secondary needs for other things. That is to say; they need food just like air and water to survive while food is supplied like other goods in the market. In this

\footnotetext{
9 - An'am surah, verses 142-143.

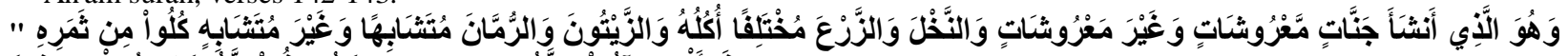

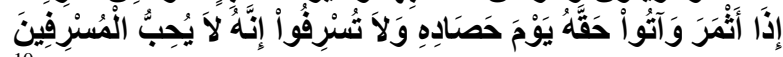

10 - An'am surah, verses 26-27.

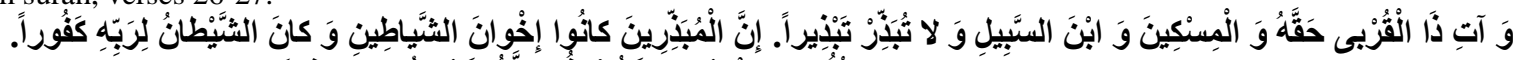

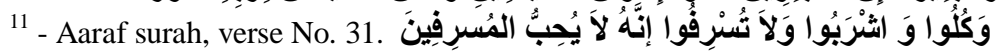


situation, in addition to people dying because of war and homelessness, some others die because of famine and starvation. Many people die because of chronic malnutrition and diseases thereof; their life becomes shorter, and they suffer more. Lack of food, the children, also suffered due to low mental and bodily growth, which threatens their future ${ }^{12}$. As a result, the human being is wasting a portion of human power and resources, which decreases the supply in the global economy. This concept can be deducted from the Quranic verse which says ${ }^{13}$ : "Eat from clean things we have sustenance for you and do not squander them which makes my anger possible and if my anger descent upon anyone, he will die".

From an economic point of view, prevention of squandering will decrease food prices and thereof; poor people can afford to consume more food. This is very important from an economic point of view, and everybody and every family need to buy as much foodstuff as it is sufficient for him, and nothing should be left to be thrown away. Therefore, people should be trained not to throw away foodstuff and instead, should give them to the poor and helpless people so that these people do not decrease their utility but reduces prices and increases their welfare as well. Certainly, good nutrition of hungry people and malnutrition people will increase their efficiency, which leads to more production increase and welfare of all people of the Earth planet.

\section{References}

http://en.wikipedia.org/wiki/List_of_waste_types

"The Definition of Waste, Summary of European Court of Justice Judgments". Defra. Updated 2009.

http://www.defra.gov.uk/environment/waste/topics/pdf/ECJCaseLaw20090209.pdf. Retrieved 2009-08-20.

http://www.fao.org/UNFAO/Bodies/cfs/cfs34/index_en.htm

http://www.iaahp.net

Olivier De Schutter, 2009, UN Special Rapporteur on the right to food, Accountability to combat hunger.

http://www.iaahp.net/fileadmin/templates/iaah/WFD2009/contributions/IAAHeditorial_DeSchutter_EN.pdf

All-Africa Global Media, Feb. 19, 2008.

Robin Shreeves, The Shocking Statistics of Food Waste (and How to Keep Your Contribution to the Problem at a Minimum) Published on August 25th, 2008, Home \& Garden

http://www.refrigeratorsaver.com/

\section{Copyrights}

Copyright for this article is retained by the author(s), with first publication rights granted to the journal.

This is an open-access article distributed under the terms and conditions of the Creative Commons Attribution license (http://creativecommons.org/licenses/by/4.0/)

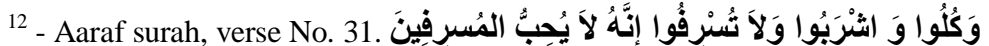

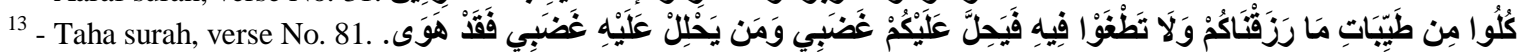

